\title{
THE RELATIONS BETWEEN CARBON ISOTOPE COMPOSITION AND APPARENT AGE OF FRESHWATER TUFACEOUS SEDIMENTS
}

\author{
ANNA PAZDUR \\ Radiocarbon Laboratory, Institute of Physics, Silesian Technical \\ University, Krzywoustego 2, PL-44-100 Gliwice, Poland
}

\begin{abstract}
This paper presents a synthetic approach to ${ }^{14} \mathrm{C}$ dating of calcareous tufa, based on statistical analysis of correlations betwen lithologic type of tufaceous sediment, carbon isotope composition, and apparent age. Experimental data on several profiles from southern Poland and the United Kingdom reveal either constant or systematically changing values of apparent age. Constant value of apparent age in a profile can be attributed to calcareous muds precipitated from stagnant or low-energy water, and to tufas precipitated from turbulent water (oncoids, stromatolites, moss travertines) which are characterized by lack of significant correlation between $\delta^{13} \mathrm{C}$ and ${ }^{14} \mathrm{C}$ age of tufa carbonate. It was found that the relation between the apparent age of tufaceous sediment and $\delta^{13} \mathrm{C}$ value of tufa carbonate depends on lithologic type of tufa. Phenomenological equations describing the dependence of apparent age upon $\delta^{19} \mathrm{C}$ are given, and applied to estimate true ages of tufas from Gliczarów (southern Poland) and Folkestone (United Kingdom).
\end{abstract}

\section{INTRODUCTION}

In recent years significant efforts have been made to study various aspects of tufaceous sediments, including sedimentology, geochemistry, and methods of dating. Increasing interest was stimulated by the importance of such sediments in reconstructing climatic variations in the past. Reliable dating methods are the key to successful application of any method of climatic reconstruction. The radiocarbon method has been regarded unsuitable for dating tufaceous sediments because of unknown and variable initial ${ }^{14} \mathrm{C}$ activity, and possible contamination from modern carbon with high specific ${ }^{14} \mathrm{C}$ activity. Initial attempts at ${ }^{14} \mathrm{C}$ dating tufaceous sediments (Thorpe, Otlet \& Sweeting, 1980; Srdoc et al, 1980, 1982, 1983) have indicated real applicability of this method to dating spring tufas. It should be noted that early studies of Broecker and Walton (1959), as well as Benson (1978), are of limited value because they were dealing with lake tufas. Model considerations of Broecker and Walton (1959) concerning initial ${ }^{14} \mathrm{C}$ activity of lake carbonate are unsuitable for dating spring tufas. However, some findings of Benson (1978) concerning diagenetic changes of tufaceous sediments, are valid also for spring tufas (Pazdur, Pazdur \& Szulc, 1988). Results of ${ }^{14} \mathrm{C}$ measurements of tufa from several sites in southern Poland indicated significant variability of initial ${ }^{14} \mathrm{C}$ activity and its dependence on sedimentologic and geochemical processes (Pazdur \& Pazdur, 1986; Pazdur, Pazdur \& Szulc, 1988). This study explores the dependence of initial ${ }^{14} \mathrm{C}$ activity of spring tufas upon isotopic composition of carbon. Radiocarbon activity of freshwater carbonate sediment at the moment of precipitation $\left(\mathrm{A}_{\mathrm{O}}\right)$ is obviously influenced by isotopic composition of carbon compounds dissolved in water. Radiocarbon studies of ground water have resulted in the formulation of different models which estimate initial ${ }^{14} \mathrm{C}$ activity of $\mathrm{HCO}_{3}{ }^{-}$ions dissolved in water (Pearson, 1965; Vogel, 1970; Mook, 1976, 1980; Eichinger, 1983). However, physicochemical processes involved in precipitation of tufa are complex, and 
numerous environmental factors may influence them (Friedman, 1970; Usdowski, Hoefs \& Menschel, 1979; Dandurand et al, 1982; Michaelis, Usdowski \& Menschel, 1985; Thorpe, Otlet \& Sweeting, 1980; Szulc, 1984). Direct application of such models in ${ }^{14} \mathrm{C}$ dating of tufa has led to unsatisfactory results (Thorpe et al, 1981; Krajcar et al, 1985).

\section{APPARENT AGE OF CARBONATE SEDIMENTS}

The radiocarbon age $\left(\mathrm{T}_{\mathrm{C}}\right)$ of carbonate sediment, determined by the ratio of measured ${ }^{14} \mathrm{C}$ activity (A) in a sample to ${ }^{14} \mathrm{C}$ activity of the contemporary biosphere $\left(\mathrm{A}_{\mathrm{ox}}\right)$, defined as $95 \%$ of the activity of NBS oxalic acid standard (Stuiver \& Polach, 1977), ie, $\mathrm{T}_{\mathrm{c}}=-8033 * \ln \left(\mathrm{A} / \mathrm{A}_{\mathrm{ox}}\right)$, is greater than the real age of sediments because of depletion of initial ${ }^{14} \mathrm{C}$ activity in precipitated carbonate with respect to the biosphere,

$$
\mathrm{A}_{\mathrm{O}}<\mathrm{A}_{\mathrm{ox}}=100 \mathrm{pmc}
$$

(pmc $=$ per cent of modern carbon).

The magnitude of this apparent age, relative to the real age $\mathrm{T}_{\mathrm{ORG}}$, can be determined experimentally by measuring the age of organic matter associated with the layer of carbonate sediment, or detrital organic matter dispersed in the carbonate, itself. Assuming that the age of organic remnants reflects the actual age of carbonate precipitation, we can define the apparent age of carbonate sediment

$$
\mathrm{T}_{\mathrm{app}}=\mathrm{T}_{\mathrm{C}}-\mathrm{T}_{\mathrm{ORG}} .
$$

The value $T_{\text {app }}$ is related to initial ${ }^{14} \mathrm{C}$ activity of carbonate $A_{O}$ and reservoir dilution factor $(q)$ through the equation

$$
\mathrm{T}_{\mathrm{app}}=-8033 * \ln \left(\mathrm{A}_{\mathrm{O}} / \mathrm{A}_{\mathrm{ox}}\right)=-8033 * \ln \mathrm{q} .
$$

Observed values of $q$ in both recent and ancient tufas usually lie from 0.5 to 0.95 (Srdoc et al, 1980, 1982, 1983; Thorpe, Otlet \& Sweeting, 1980; Thorpe et al, 1981; Pazdur \& Pazdur, 1986). Consequently, the values of $\mathrm{T}_{\text {app }}$ are included in the interval

$$
500 \mathrm{yr}<\mathrm{T}_{\text {app }}<5500 \mathrm{yr} \text {. }
$$

In dating speleothems, it is commonly assumed that $\mathrm{q}=0.85\left(\mathrm{~A}_{\mathrm{O}}=85 \mathrm{pmc}\right)$ corresponding to an age of $1300 \mathrm{yr}$. Such a value $\left(\mathrm{A}_{\mathrm{O}}=85 \mathrm{pmc}\right)$ is also presumed for tufas by Srdoc et al $(1980,1982,1983)$. Although they have observed significantly lower values of $\mathrm{A}_{\mathrm{O}}$ (as low as up to ca $70 \mathrm{pmc}$ ) in carbonates precipitated in streams, they have observed values close to $85 \mathrm{pmc}$ in stagnant water carbonates.

Thus, it seems that the scatter of the values of $\mathrm{T}_{\mathrm{app}}$, observed by various authors (Srdoc et al, 1980, 1982, 1983; Thorpe, Otlet \& Sweeting, 1980; Thorpe et al, 1981; Pazdur \& Pazdur, 1986; Pazdur, Pazdur \& Szulc, 1988) could be explained by the dependence of $\mathrm{T}_{\mathrm{app}}$ on the bedrock type (which is a source of ${ }^{14} \mathrm{C}$-free carbon) and the type of sediment (Szulc, 1984, 1986). The type of calcareous sediments depends strongly on hydrodynamic conditions of water flow. Detailed classification of tufaceous deposits, based on 
their lithological properties and geochemical and biological conditions of sedimentation, has been described by Pazdur, Pazdur and Szulc (1988). For present consideration, a slightly simplified classification seems appropriate:

1) Spring tufa: Precipitated in a turbulent water flow (oncoids, stromatolites, moss travertines). As a rule, minute amounts of organic matter in these deposits do not allow for determination of $\mathrm{T}_{\text {app }}$ by comparison of $\mathrm{T}_{\mathrm{C}}$ and $\mathrm{T}_{\mathrm{ORG}}$ (the Racławka and Gliczarów sites).

2) Tufas (oncoids, moss travertines) and peloidic calcareous muds: Precipitated in streams with low or variable water flow. Calcareous muds with large amounts of humus allow for determination of $\mathrm{T}_{\text {app }}$ by measuring of $\mathrm{T}_{\mathrm{C}}$ and $\mathrm{T}_{\mathrm{ORG}}$ (the Rzerzuśnia and Trzebienice sites).

3) Calcareous muds with large amounts of organic matter: Precipitated in shallow, stagnant-water basins in conditions similar to semilimnic sedimentation (the Sieradowice site).

The factors determining the sedimentary regime of freshwater carbonates should be reflected by isotopic composition of carbon $\left(\delta_{c}^{13} \mathrm{C}, \mathrm{A}_{\mathrm{O}}\right)$ in carbonate samples and should influence the value of $\mathrm{T}_{\text {app }}$. For recently deposited tufas, a significant relation between $\delta_{\mathrm{c}}{ }^{13} \mathrm{C}$ and the turbulence of water flow is suggested by models that consider the effects of changes of water chemistry, caused by diffusional escape of $\mathrm{CO}_{2}$ on the course of carbonate precipitation (Usdowski, Hoefs \& Menschel, 1979; Dandurand et al, 1982; Michaelis, Usdowski \& Menschel, 1985).

\section{ISOTOPIC COMPOSITION OT TUFA CARBONATE}

A detailed list of ${ }^{14} \mathrm{C}$ dates $\left(\mathrm{T}_{\mathrm{C}}\right.$ and $\left.\mathrm{T}_{\mathrm{ORG}}\right)$ together with corresponding values of $\delta_{\mathrm{c}}{ }^{13} \mathrm{C}$ and $\mathrm{T}_{\mathrm{app}}$ for Holocene tufa from southern Poland has been presented elsewhere (Pazdur, Pazdur \& Szulc, 1988). Values of $\delta_{c}{ }^{13} \mathrm{C}$ of carbonate samples are plotted in Figure 1 against their carbonate age $\left(\mathrm{T}_{\mathrm{C}}\right)$ and, whenever available, against the age of corresponding organic fraction $\left(T_{O R G}\right)$. The $T_{C}$ values for the Folkestone and Thatcham Reedbeds profiles in the United Kingdom were calculated by the author from the data quoted by Thorpe et al (1981). Smoothed dependence of $\delta_{\mathrm{c}}{ }^{13} \mathrm{C}$ upon $\mathrm{T}_{\mathrm{C}}$ (and/or $\mathrm{T}_{\mathrm{ORG}}$ ) is shown in Figure 1 by solid lines

$$
\delta_{\mathrm{c}}^{13} \mathrm{C}=\mathrm{a}_{\mathrm{OC}}+\mathrm{a}_{1 \mathrm{C}} \mathrm{T}_{\mathrm{C}}
$$

and

$$
\delta_{\mathrm{c}}{ }^{13} \mathrm{C}=\mathrm{a}_{\mathrm{OR}}+\mathrm{a}_{1 \mathrm{R}} \mathrm{T}_{\text {ORG }}
$$

obtained by the least squares method. Parameters of the least squares line $\left(\mathrm{a}_{\mathrm{OC}}, \mathrm{a}_{1 \mathrm{C}}, \mathrm{a}_{\mathrm{OR}}, \mathrm{a}_{1 \mathrm{R}}\right)$, the value of correlation coefficient $\mathrm{r}$, and number $(\mathrm{n})$ of experimental points used in calculation are listed in Table 1. Two samples with distinctly outlying high values of $\delta_{\mathrm{c}}{ }^{13} \mathrm{C}(\mathrm{ca}-6.5 \%)$, collecied from disturbed parts of Rzerzuśnia profile near the erosional surfaces, were not included. Mean values of $\delta_{c}{ }^{3} \mathrm{C}$ are quoted in Table 1 for those profiles where the dependence of $\delta_{\mathrm{c}}{ }^{13} \mathrm{C}$ upon $\mathrm{T}_{\mathrm{C}}$ seems to be insignificant (ie, Rzerzuśnia, Trzebienice, Racławka, Thatcham Reedbeds). 


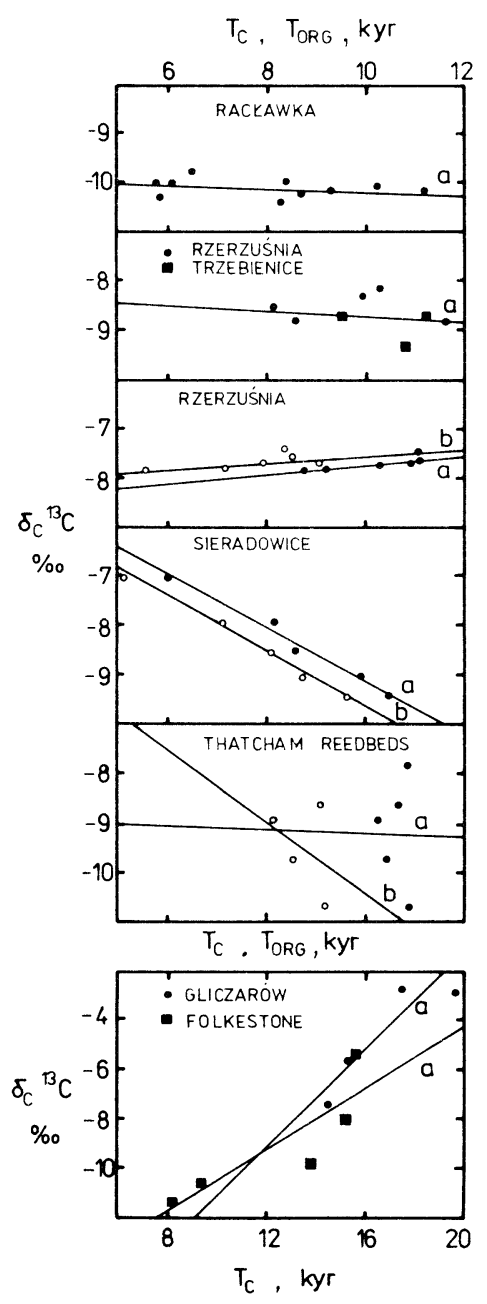

Fig 1. Dependence of $\delta_{\mathrm{c}}{ }^{13} \mathrm{C}$ upon $\mathrm{T}_{\mathrm{C}}$ and $\mathrm{T}_{\mathrm{ORG}}$ : a-straight line described by Eq (5); $\mathrm{b}$-straight line described by Eq (6).

It appears that samples of spring tufas from different profiles, developed on the same limestone bedrock by water having similar energy (Rzerzuśnia, Trzebienice) show similar mean values of $\delta_{\mathrm{c}}{ }^{13} \mathrm{C}$. On the other hand, different values of $\delta_{\mathrm{c}}{ }^{13} \mathrm{C}$ may be observed in tufas of the same type, but developed on different bedrock by water having different flow (Rzerzuśnia, Trzebienice, Racławka). It should be also noted that samples of tufa from the Rzerzuśnia profile have lower $\delta_{c}^{13} \mathrm{C}$ value than calcareous muds from the same site. Unfortunately, detailed sedimentologic classification of tufa deposits from the UK sites (Folkestone and Thatcham Reedbeds) is not available. Identical (within the limits of measurement error) mean values of $\delta_{\mathrm{c}}{ }^{13} \mathrm{C}$ from the Thatcham Reedbeds carbonates and from spring tufas from Rzerzuśnia, both developed on the same Cretaceous bedrock, suggest that most samples from sites studied by Thorpe et al (1981) could be classified as 

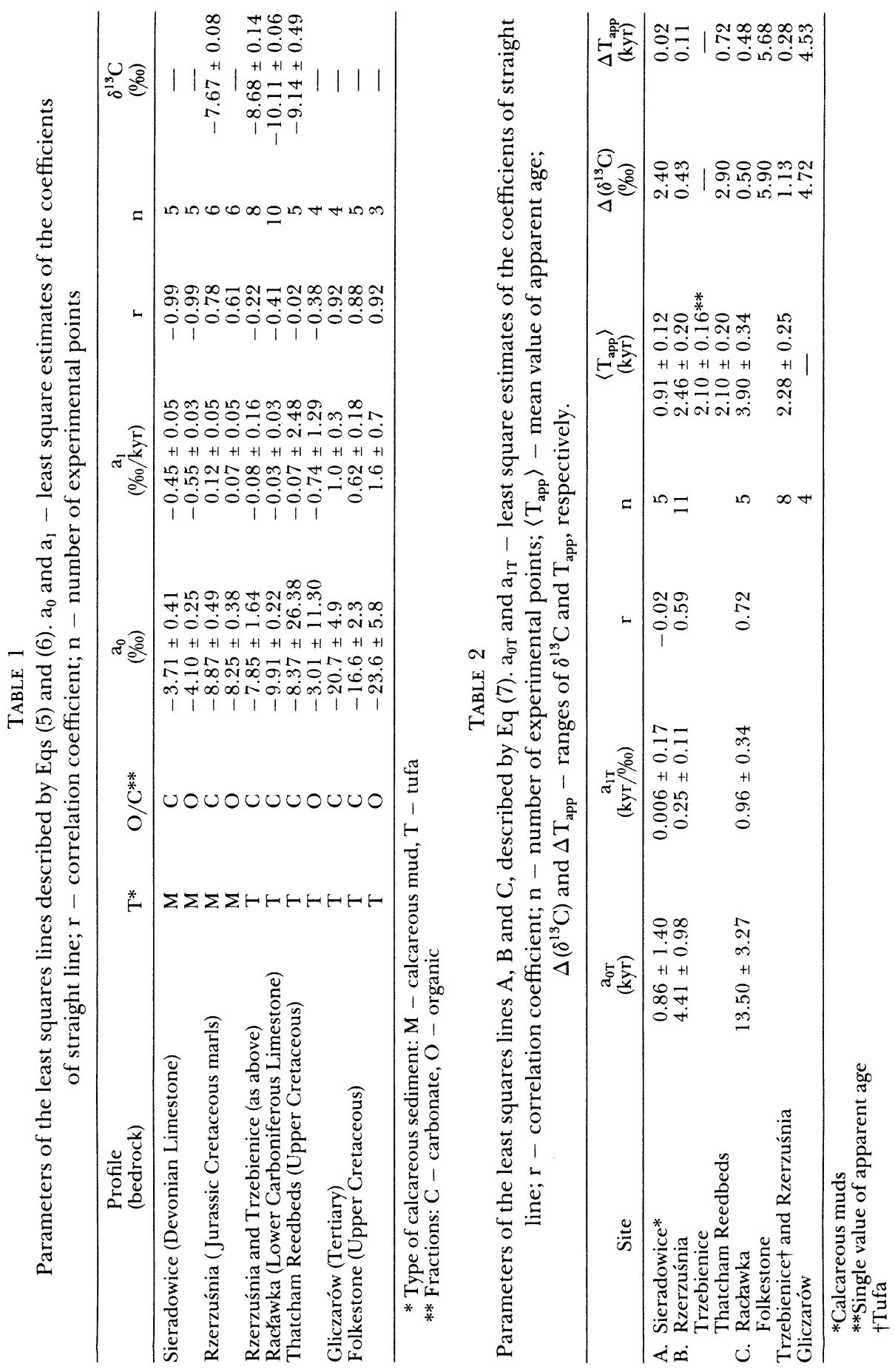
spring tufas. We therefore conclude that different trends of $\delta_{\mathrm{c}}{ }^{13} \mathrm{C}$ with time, and different correlations of $\delta_{\mathrm{c}}{ }^{13} \mathrm{C}$ and $\mathrm{T}_{\mathrm{C}}$, can be regarded as indicators of significant dependence of isotopic composition of carbon in tufaceous sediments upon the conditions during sedimentation, or, more precisely, upon bedrock type and hydrodynamic conditions (energy of water flow).

\section{RELATION BETWEEN ISOTOPIC COMPOSITION OF CARBON AND APPARENT AGE}

The relation between experimentally determined values of $\mathrm{T}_{\text {app }}(\mathrm{Eq} 2)$ and $\delta_{\mathrm{c}}{ }^{13} \mathrm{C}$ in samples from all profiles in southern Poland and two sites from the UK (Folkestone and Thatcham Reedbeds) is shown in Figure 2. Three groups of points are clearly distinguished in this data set and, apparently, each group of points can describe the linear function

$$
\mathrm{T}_{\mathrm{app}}=\mathrm{a}_{\mathrm{OT}}+\mathrm{a}_{1 \mathrm{~T}} \delta_{\mathrm{c}}{ }^{13} \mathrm{C}
$$

with a reasonably high confidence level. The straight lines denoted as A, B, and $\mathrm{C}$ (Fig 2) represent the least squares lines (7) determined by corresponding groups of points. Values of the parameters $\mathrm{a}_{\mathrm{OT}}$ and $\mathrm{a}_{1 \mathrm{~T}}$, coefficients of correlation $r$ and numbers of points $(n)$ are given in Table 2. The possibility of three different linear approximations of the relationship between $\mathrm{T}_{\mathrm{app}}$ and $\delta_{\mathrm{c}}^{13} \mathrm{C}$ clearly indicates a dependence of $\mathrm{T}_{\mathrm{app}}$ on tufa and bedrock types.

Experimental data from the Sieradowice profile, developed on Devonian limestone, indicate lack of significant correlation of $\mathrm{T}_{\text {app }}$ and $\delta_{\mathrm{c}}{ }^{13} \mathrm{C}$, despite relatively large changes in $\delta_{c}{ }^{13} \mathrm{C}\left(\Delta \delta_{c}{ }^{13} \mathrm{C}=+2.4 \%\right)$. The low value of apparent age $\left(\mathrm{T}_{\mathrm{app}}=910 \pm 120 \mathrm{yr}\right)$ and distinctly secular trend of $\delta_{\mathrm{c}}{ }^{13} \mathrm{C}$, may be regarded as typical features of limnic sedimentation (Geyh, 1970, 1983). Line B (Fig 2) approximates results from profiles in Rzerzuśnia and Trzebienice (bedrock: Upper Jurassic and Middle Cretaceous marls and limestones; low energy of water flow) and from the Thatcham Reedbeds site in UK (bedrock: Upper Cretaceous; water flow). Calcareous muds with large

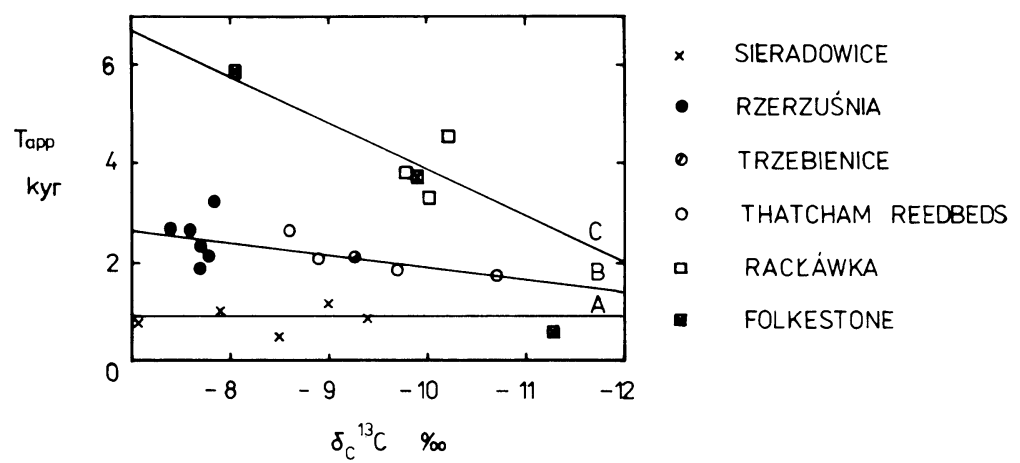

Fig 2. Relation between experimentally determined values of $\mathrm{T}_{\text {app }}$ and $\delta_{\mathrm{c}}{ }^{18} \mathrm{C}$ for all described profiles from S Poland and UK (Folkestone, Thatcham Reedbeds; Thorpe et al, 1981). 
amounts of organic matter are intercalated in the Rzerzuśnia profile between levels of tufa sediments consisting of pure carbonate (Szulc, 1984; Pazdur, Pazdur \& Szulc, 1988). Apparent age of sediments from the Thatcham Reedbeds was evaluated by comparing the ${ }^{14} \mathrm{C}$ ages of carbonates and of detrital organic matter dispersed within the tufaceous sediment, according to values quoted by Thorpe et al (1981).

Tufas with high values of $T_{\text {app }}$, independently of the kind of bedrock (Racławka: Lower Carboniferous; high energy of water flow; Folkestone: Upper Cretaceous; water flow) can be described by a common dependence of $\mathrm{T}_{\text {app }}$ upon $\delta_{\mathrm{c}}{ }^{13} \mathrm{C}$ shown by line $\mathrm{C}$ (Fig 2). One outlying result, from the Folkestone profile, corresponding to $\mathrm{T}_{\mathrm{app}}=580 \mathrm{yr}$, was rejected from the data used to calculate the equation of line $\mathrm{C}$.

Table 2 also lists mean values of $\mathrm{T}_{\mathrm{app}}$ with corresponding mean square standard deviations $\left.\left(<\Delta \mathrm{T}_{\mathrm{app}}\right\rangle\right)$ for those profiles, in which the dependence of $\mathrm{T}_{\text {app }}$ upon $\delta_{\mathrm{c}}{ }^{13} \mathrm{C}$ seems to be insignificant. Table 2 also gives ranges of $\delta_{\mathrm{c}}{ }^{13} \mathrm{C}$ in a given profile for specified sediment classes, and corresponding intervals of $\mathrm{T}_{\text {app }}$ calculated from the equations for lines $\mathrm{A}, \mathrm{B}$, and $\mathrm{C}$. The relations between $\Delta \mathrm{T}_{\text {app }}$ and $\Delta \delta_{\mathrm{c}}{ }^{13} \mathrm{C}$ are shown in Figure 3, which incorporates values of $\left\langle\mathrm{T}_{\text {app }} \pm \Delta \mathrm{T}_{\text {app }}\right\rangle$. The interval of $\Delta \mathrm{T}_{\text {app }}$ for moss travertines from the Gliczarow site, for which the values of apparent age were not determined experimentally, has been evaluated from equation of line $\mathrm{C}$ (see Table 2). This step is justified by a similar secular trend of $\delta_{\mathrm{c}}{ }^{13} \mathrm{C}$ variations in sediments from the Gliczarów and Folkestone profiles (Fig 1), and by similar range of $\delta_{\mathrm{c}}{ }^{13} \mathrm{C}$ values in both profiles (Table 3).

\section{TUFACEOUS SEDIMENTS WITH CONSTANT VALUE OF APPARENT AGE}

Experimentally determined values of apparent age in each of the studied profiles show scatter, significantly exceeding intervals of measurement errors (Fig 3). Therefore, it seems necessary to select a criterion which should help decide if the value of apparent age in a given profile could be regarded constant or not. The form of such criterion issues from a comparison of the natural scatter of $\mathrm{T}_{\mathrm{app}}$ values, which are measured by mean

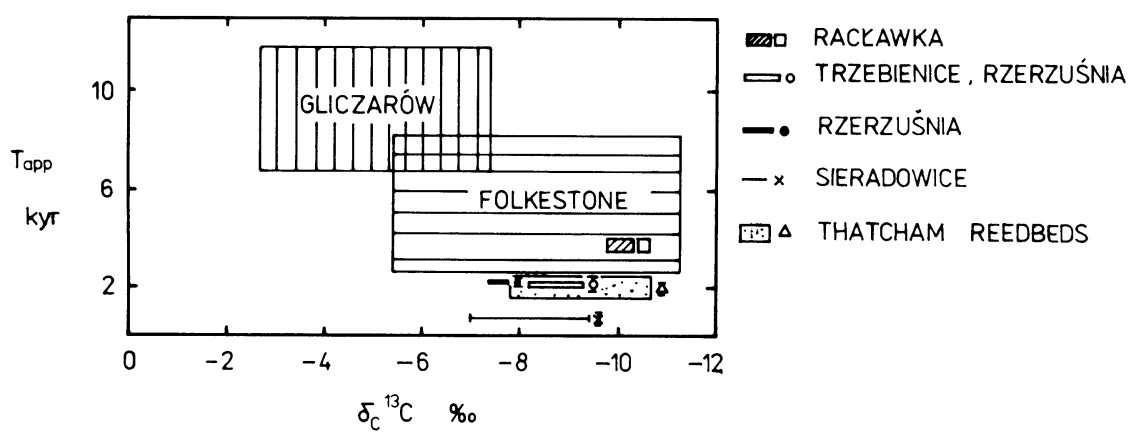

Fig 3. Mean values of the apparent age $\left(<\mathrm{T}_{\mathrm{app}}>\right)$ and observed ranges of $\delta_{\mathrm{c}}{ }^{13} \mathrm{C}$ in studied tufa profiles and related intervals of $\Delta \mathrm{T}_{\text {app }}$ estimated from the equation of straight line $\mathrm{A}, \mathrm{B}$, or $\mathrm{C}$. 
TABLE 3

A comparison of measured values of the apparent age $\left(T_{\text {app }}\right)$ with theoretical values $\mathrm{T}_{\mathrm{pr}}$ predicted by Eq 8 (curve $\mathrm{C}$ ).

\begin{tabular}{llccccccc}
\hline \multicolumn{1}{c}{ Site } & \multicolumn{1}{c}{ Sample } & $\begin{array}{c}\text { Depth } \\
(\mathrm{cm})\end{array}$ & $\begin{array}{c}\mathrm{T}_{\mathrm{c}} \\
(\mathrm{yr})\end{array}$ & $\begin{array}{c}\mathrm{T}_{\text {ORG }} \\
(\mathrm{yr})\end{array}$ & $\begin{array}{c}\delta_{\mathrm{c}}{ }^{13} \mathrm{C} \\
(\%)\end{array}$ & $\begin{array}{c}\mathrm{T}_{\text {app }} \\
(\mathrm{yr})\end{array}$ & $\begin{array}{c}\mathrm{T}_{\text {app }}^{\mathrm{r}} \\
(\mathrm{yr})\end{array}$ & $\begin{array}{c}\mathrm{T}_{\mathrm{pr}} \\
(\mathrm{yr})\end{array}$ \\
\hline Folkestone & HAR-3987 & $91-95$ & 8080 & 7500 & -11.3 & 580 & $2650 \pm 500$ & 5430 \\
Kent, UK & HAR-3094 & $94-99$ & 9320 & - & -10.5 & - & $3420 \pm 320$ & 5900 \\
& HAR-3900 & $112-116$ & 15.610 & - & -5.4 & - & $8320 \pm 1120$ & 7280 \\
& HAR-3902 & $125-140$ & 12.670 & 8900 & -9.9 & 3770 & $4000 \pm 230$ & 8670 \\
& HAR-3690 & $160-185$ & 15.220 & 9300 & -8.0 & 5920 & $5820 \pm 460$ & 9400 \\
Gliczarów & G12/83 & & 15.280 & - & -5.56 & - & $8160 \pm 1080$ & 7120 \\
Podhale & G11/83 & & 19.680 & - & -2.76 & - & $10.850 \pm 1800$ & 8830 \\
S Poland & G115/83 & & 17.490 & - & -2.67 & - & $10.940 \pm .1830$ & 6550 \\
& G1-Id & & 14.530 & - & -7.39 & - & $6410 \pm 610$ & 8120 \\
\hline
\end{tabular}

square standard deviation, $\left\langle\Delta \mathrm{T}_{\text {app }}\right\rangle$, with the range of $\Delta \mathrm{T}_{\text {app }}$ determined by the corresponding equations of line $\mathrm{A}, \mathrm{B}$, or $\mathrm{C}$. Therefore, the profiles of tufa sediments for which the following inequality

$$
<\Delta \mathrm{T}_{\text {app }}>>\Delta \mathrm{T}_{\text {app }}
$$

is valid, could be regarded as obeying the constant value of $T_{\text {app }}$. As can be seen from Table 2, this condition is fulfilled by all profiles except sediments of the Gliczarów and Folkestone sites. For those sites the assumption of constant value of apparent age cannot be accepted.

In Figure 4 mean values of apparent age are plotted against values of $\delta_{\mathrm{c}}^{13} \mathrm{C}$ extrapolated to $\mathrm{T}_{\mathrm{C}}=0 ; i e, \mathrm{a}_{\mathrm{OC}}=\delta_{\mathrm{c}}{ }^{13} \mathrm{C}\left(\mathrm{T}_{\mathrm{C}}=0\right)$, according to $\mathrm{Eq}(5)$. Two points representing calcareous muds from the Sieradowice and Rzerzuśnia profiles reveal significant correlation between $\delta_{\mathrm{c}}{ }^{13} \mathrm{C}$ and $\mathrm{T}_{\mathrm{C}}$. The other points represent sediments for which the extrapolated value $\left(\mathrm{a}_{\mathrm{OC}}\right)$ coincides with the mean value of $\delta_{c}{ }^{13} \mathrm{C}$ in the profile. In linear approximation, the relation shown in Figure 4 can be described by the least squares line with equation:

$$
<\mathrm{T}_{\text {app }}>=(-0.78 \pm 1.63)-(0.40 \pm 0.20) \mathrm{a}_{\mathrm{OC}}
$$

where $\mathrm{a}_{\mathrm{OC}}$ is expressed in $\% 0$ vs $\mathrm{PDB}$, and $<\mathrm{T}_{\text {app }}>$ in kyr BP. Broken lines in Figure 4 denote confidence intervals of $\mathrm{T}_{\text {app }}$ for the given value of $\mathrm{a}_{\mathrm{OC}}$ corresponding to the $1 \sigma$ confidence level.

The high value of correlation coefficient described by Eq (9) $(r=$ -0.90 ) shows that, in profiles with constant apparent age, the $\mathrm{T}_{\text {app }}$ value is determined by isotopic composition of carbon in the profile, independently of the type of tufa (calcareous muds, stromatolites, oncoids, moss travertines) and kind of bedrock. A constant value of the apparent age in a certain profile can be attributed to:

1) Calcareous muds, precipitated from stagnant or low energy water. Examples of such deposits are given by profiles in Rzerzuśnia and Sieradowice. For such deposits significant correlation between $\delta_{\mathrm{c}}{ }^{13} \mathrm{C}$ and $\mathrm{T}_{\mathrm{C}}$ do not influence the value of apparent age.

2) Tufas precipitated in turbulent water flow (oncoids, stromatolites, moss travertines) which are characterized by lack of significant correlation 


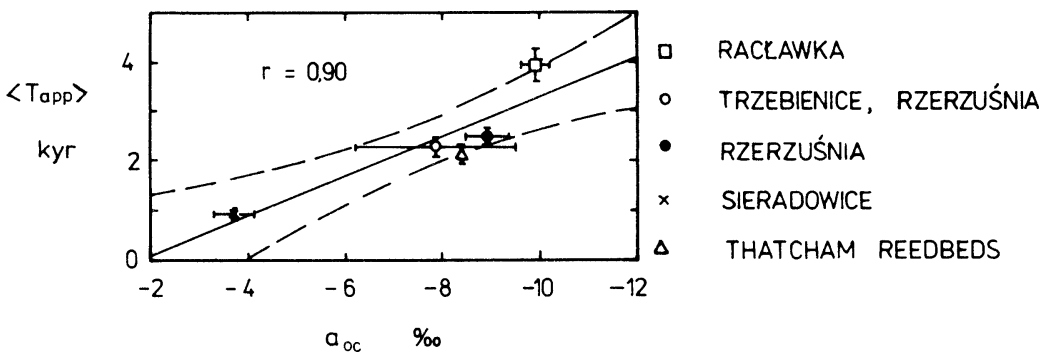

Fig 4. Dependence of the mean value of apparent age $\left(<\mathrm{T}_{\mathrm{app}}>\right)$ upon the value of $\delta_{\mathrm{c}}{ }^{13} \mathrm{C}$ extrapolated to $T_{C}=0$ according to $E q(5)$ for tufa profiles with constant value of $T_{\text {app }}$. Solid line-straight line described by Eq (9); broken lines- $1 \sigma$ limits for $<\mathrm{T}_{\text {app }}>$.

between $\delta_{c}^{13} \mathrm{C}$ and $\mathrm{T}_{\mathrm{C}}$. Examples of such deposits are presented by profiles in Racławka, Rzerzuśnia, and Trzebienice.

\section{TUFACEOUS SEDIMENTS WITH VARIABLE VALUE OF APPARENT AGE}

Tufas in the Gliczarów and Folkestone sites show a similar and distinct dependence of $\delta_{c}^{13} \mathrm{C}$ upon $\mathrm{T}_{\mathrm{C}}$ (see Table 1). In the Gliczarów site, moss travertines and stromatolites do not form a single profile but occur in clusters on a hill slope (Szulc, 1984). Experimental determination of the apparent age was not possible for dated samples from the Gliczarów site, but the values of $T_{\text {app }}$ obtained for the Folkestone profile exclude the possibility of constant $T_{\text {app }}$. Therefore, sediments of both sites are considered jointly, basing similarity on the equation of line $\mathrm{C}$ in Figure 2( $\mathrm{Eq} 8$ ). Table 3 lists all experimental data from both profiles, as well as values of the apparent age $\mathrm{T}_{\text {app }}^{\mathrm{C}}$ predicted by Eq 8 of line $\mathrm{C}$ in Figure 2, together with the errors $\Delta \mathrm{T}_{\text {app }}^{\mathrm{C}}$ determined by linear approximation.

Predicted values of true age of dated tufa samples, defined as $\mathrm{T}_{\mathrm{pr}}=$ $\mathrm{T}_{\mathrm{C}}-\mathrm{T}_{\mathrm{app}}^{\mathrm{C}}$, are listed in the last column in Table 3. Errors of those values are practically the same as the errors of determination of the values of $\mathrm{T}_{\text {app. }}^{\mathrm{C}}$.

No sedimentologic information on deposits in the Folkestone profile has been published by Thorpe et al (1981). However, the data quoted in Table 2 indicate that the profile is bipartite. Its uppermost part $(91-99 \mathrm{~cm})$ is characterized by an enormously low value of apparent age (580 yr) and low sedimentation rate (ca $0.2 \mathrm{~mm} / \mathrm{yr})$. In the lower part of the profile sedimentation rate is equal to ca $1.5 \mathrm{~mm} / \mathrm{yr}$, and experimentally determined values of apparent age are high $(3770$ and $5920 \mathrm{yr})$. These values are close to those found for tufa deposited in high-energy turbulent water flow (Pazdur, Pazdur \& Szulc, 1988). Values of apparent age predicted by line C (Fig 2) should therefore be applied only to the tufa from the lowermost part of the Folkestone profile, ranging from 112 to $185 \mathrm{~cm}$ depth.

It should be noted that predicted ages of samples from the Folkestone profile do not show age inversions which can be seen in the column of carbonate ages $T_{C}$. Relatively large errors of estimated apparent age values for samples from the Gliczarów site are caused by inherent inaccuracy connected with extrapolation of the dependence of $\mathrm{T}_{\text {app }}$ upon $\delta_{\mathrm{c}}{ }^{13} \mathrm{C}$ beyond the 
interval of its experimental verification. As quoted by Pazdur, Pazdur and Szulc (1988), there are different geologic opinions concerning the age of tufas from the Gliczarów site. Present age estimates are consistent with the results of malacologic studies of Alexandrowicz (1985) which suggest an early Holecene age for sample G1-Id.

\section{DISCUSSION}

Despite several studies of the sedimentation process of recent tufaceous deposits, a quantitative description of the relation between initial ${ }^{14} \mathrm{C}$ activity of fossil tufas and chemical and isotopic composition of a complex open system seems to be unfeasible as yet. In any case, it is to be expected that final isotopic composition of carbon in the carbonate sediment $\left(\mathrm{A}_{\mathrm{O}}\right.$, $\delta_{\mathrm{c}}{ }^{13} \mathrm{C}$ ) should reflect the features of the carbon cycle in such a system. Thus, it seems worthwhile to search for some empirical relations between directly measurable parameters $\left(\mathrm{T}_{\mathrm{C}}, \mathrm{T}_{\mathrm{ORG}}, \mathrm{T}_{\mathrm{app}}, \delta_{\mathrm{c}}{ }^{13} \mathrm{C}\right)$ even if we are unable to explain and understand all the physicochemical processes which lead to those relations.

Regarding a model description of processes of tufa sedimentation, the Racławka profile seems to be particularly interesting. The experimentally determined mean value of the apparent age for this site is $\left\langle\mathrm{T}_{\mathrm{app}}\right\rangle=3900 \pm$ $350 \mathrm{yr}$, which corresponds to initial ${ }^{14} \mathrm{C}$ activity of carbonate equal to $\mathrm{A}_{\mathrm{O}}=62 \mathrm{pmc}$. The value of $\delta_{1}{ }^{13} \mathrm{C}$ of the Lower Carboniferous limestones, which form the bedrock for deposition of tufas in this site, is equal to $\delta_{1}{ }^{13} \mathrm{C}=+2.42 \%$ while mean value of $\delta^{13} \mathrm{C}$ in the profile is equal to $<\delta_{\mathrm{c}}{ }^{13} \mathrm{C}>=-10.11 \%$. Initial ${ }^{14} \mathrm{C}$ activity of tufa sediments, calculated on the basis of the closed system assumption

$$
\mathrm{A}_{\mathrm{O}}=\frac{\left\langle\delta_{\mathrm{c}}{ }^{13} \mathrm{C}>-\delta_{1}{ }^{13} \mathrm{C}\right.}{\delta_{0}{ }^{13} \mathrm{C}-\delta_{1}{ }^{13} \mathrm{C}}
$$

$\left(\delta_{0}{ }^{13} \mathrm{C}=25 \%\right.$, Pearson, 1965) is equal to 55 pmc. Quoted values of $\mathrm{A}_{\mathrm{O}}$ (obtained directly from measurements and from the closed system equation) may be regarded as similar, or even coincident, within the limits of errors. This similarity indicates that the sediments truly reflect the isotopic composition of carbon dissolved in water and, moreover, it suggests that the effect of evaporation during sedimentation of tufa in turbulent water is negligible. For tufaceous deposits in the Rzerzuśnia and Trzebienice profiles, experimentally determined values of $\left\langle\delta_{c}^{13} \mathrm{C}>\right.$ and $\mathrm{A}_{\mathrm{O}}$ are $-8.86 \%$ and 75 pmc, respectively. Assumption of the closed system model is unsuitable in this case, because the value of $\delta^{13} \mathrm{C}$ of the bedrock limestone should be as high as $\delta_{1}{ }^{13} \mathrm{C} \cong+40 \%$ to achieve compatibility of measured and predicted values of $A_{O}$. Similarly, the closed system model is invalid for calcareous muds in the Sieradowice profile because the value of $A_{O}$ is constant while the values of $\delta_{\mathrm{c}}{ }^{13} \mathrm{C}$ are systematically changing in the profile.

\section{CONCLUSIONS}

Radiocarbon dating of tufaceous sediments should be associated with detailed sedimentologic studies and $\delta^{13} \mathrm{C}$ measurements. Estimating true 
ages of individual tufa layers is relatively easy even when few organic levels can be found in the investigated profile. In such a case, measured values of ${ }^{14} \mathrm{C}$ ages of carbonate and organic fractions can be correlated with $\delta^{13} \mathrm{C}$ values of tufa carbonate. A constant value of $\delta_{c}{ }^{13} \mathrm{C}$ in the profile indicates a constant value of apparent age, which can be determined independently by comparing ${ }^{14} \mathrm{C}$ ages of carbonate and associated organics.

Profiles of tufaceous sediments that do not contain organics, but may be characterized by constant value of apparent age, can be dated with acceptable accuracy. It was found, that constant $\mathrm{T}_{\text {app }}$ value in a profile reveals peloidal calcareous muds precipitated from stagnant or low-energy water, and tufas precipitated from turbulent water (oncoids, stromatolites, and moss travertine) which do not exhibit significant correlation of $\delta_{c}{ }^{13} \mathrm{C}$ and ${ }^{14} \mathrm{C}$ age of tufa carbonate. Estimating apparent age, in such a case, is possible from $\mathrm{Eq} 9$, which describes dependence of $\mathrm{T}_{\text {app }}$ on mean value of $\delta_{c}^{13} \mathrm{C}$ in a tufa profile. Significance of this relationship is supported by a high value of correlation coefficient $(r=0.9)$.

Tufa profiles with variable values of $\mathrm{T}_{\text {app }}$ and no organics may sometimes be dated by analogy with other profiles of known dependence of $\mathrm{T}_{\text {app }}$ upon $\delta_{c}{ }^{13} \mathrm{C}$, as was shown by example of tufas from Gliczarów and Folkestone. Dating single tufa layers with no organics does not seem possible even if the lithologic type of tufa is known and $\delta^{13} \mathrm{C}$ was measured.

\section{ACKNOWLEDGMENTS}

This study was performed with financial support from Central Research Project CPBP 01.04 to the Radiocarbon Laboratory.

\section{REFERENCES}

Alexandrowicz, S W, 1985, Malacofauna of the Holocene calcareous tufa from Podhale and Pieniny Mts, in Carpatho-Balkan Assoc, cong, 13th, Proc Repts: Geol Inst Cracow, p $7-10$.

Benson, L V, 1978, Fluctuation in the level of pluvial Lake Lahontan during the last 40,000 years: Quaternary Research, v 9, p 300-318.

Broecker, W S and Walton, A, 1959, The geochemistry of $\mathrm{C}^{14}$ in fresh-water systems: Geochim et Cosmochim Acta, v 16, p 15-38.

Dandurand, J L, Gout, R, Hoefs, J, Menschel, G, Schott, J and Usdowski, E, 1982, Kinetically controlled variations of major components and carbon and oxygen isotopes in calciteprecipitating spring: Chemical Geol, v 36, p 299-315.

Eichinger, $\mathrm{L}, 1983$. A contribution to the interpretation of ${ }^{14} \mathrm{C}$ groundwater ages considering the example of a partially confined aquifer, in Stuiver, $\mathrm{M}$ and $\mathrm{Kra}, \mathrm{R} \mathrm{S}$, Internatl ${ }^{14} \mathrm{C}$ conf, 11 th, Proc: Radiocarbon, v 25, no. 2, p 347-356.

Friedman, I, 1970, Some investigations of the deposition of travertine from hot springs. I. The isotopic chemistry of a travertine depositing spring: Geochim et Cosmochim Acta, v 34, p 1303-1315

Geyh, M A, 1970, Zeitliche Abgrenzungen von Klimaänderungen mit ${ }^{14} \mathrm{C}-$ Daten von Kalksinter und organischen Substanzen: Geol Jahrb, v 98, p 15-22.

1983, Use of stable isotopes for reconstruction of paleoclimatic conditions: Quaternary Studies in Poland, v 4, p 61-71.

Krajcar, I, Horvatincic, N, Srdoc, D and Obelic, B, 1985, On the initial ${ }^{14} \mathrm{C}$ activity in Karst aquifers with short mean residence time, in Internatl ${ }^{14} \mathrm{C}$ conf, $12 \mathrm{th}$, Abs: Trondheim, Tapir, p154.

Michaelis, J, Usdowski, E and Menschel, G, 1985, Partitioning of ${ }^{18} \mathrm{C}$ and ${ }^{12} \mathrm{C}$ on the degassing of $\mathrm{CO}_{2}$ and the precipitation of calcite-Rayleigh-type fractionation and a kinetic model: Am Jour Sci, v 285, no. 4, p 318-327.

Mook, W G, 1976, The dissolution-exchange model for dating groundwater with ${ }^{14} \mathrm{C}$, in Interpretation of environmental and isotope data in groundwater hydrology: IAEA, Vienna, p 213-225. 
Mook, W G, 1980, Carbon-14 in hydrogeological studies, in Fritz, P and Fontes, J Ch, eds, Handbook of environmental isotope geochemistry, vol 1, The terrestrial environment: Amsterdam, Elsevier, p 49-74.

Pazdur, A and Pazdur, M F, 1986, ${ }^{14} \mathrm{C}$ dating of calcareous tufa from different environments, in Stuiver, $M$ and Kra, R S, eds, Internat ${ }^{14} \mathrm{C}$ conf, 12 th, Proc: Radiocarbon, v 28, no. 2A, p 534-538.

Pazdur, A, Pazdur, M F and Szulc, J, 1988, Radiocarbon dating of Holocene calcareous tufa in southern Poland: Radiocarbon, $v 30$, in press.

Pearson, F J, Jr, 1965, Use of ${ }^{13} \mathrm{C} /{ }^{12} \mathrm{C}$ ratios to correct radiocarbon ages of materials initially diluted by limestones, in Chatters, $\mathrm{R} \mathrm{M}$ and Olson, E A, eds, Internatl conf on ${ }^{14} \mathrm{C}$ and tritium dating, 6th, Proc: Clearinghouse for fed sci and tech inf, Natl Bur Standards, Washington, DC, p 357-366.

Srdoc, D, Horvatincic, N, Obelic, B and Sliepcevic, A, 1982, Rudjer Boskovic Institute radiocarbon measurements VII: Radiocarbon, v 24, p 352-371.

1983, Radiocarbon dating of tufa in paleoclimatic studies, in Stuiver, M and Kra, $\mathrm{R} \mathrm{S}$, eds, Internatl ${ }^{14} \mathrm{C}$ conf, 11 th, Proc: Radiocarbon, v 25, no. 2, p 421-427.

Srdoc, D, Obelic, B, Horvatincic, N and Sliepcevic, A, 1980, Radiocarbon dating of calcareous tufa: How reliable results can we expect? in Stuiver, $M$ and Kra, R S, eds, Internatl ${ }^{14} \mathrm{C}$ conf, 10th, Proc: Radiocarbon, v 22, no. 3, p 858-862.

Stuiver, $M$ and Polach, H A, 1977, Discussion: Reporting of ${ }^{14} \mathrm{C}$ data: Radiocarbon, v 19, no. 3, p 355-363.

Szulc, J, (ms), 1984, Sedimentation of the Quaternary travertines in southern Poland: $\mathrm{Ph} \mathrm{D}$ thesis, Pol Acad Sci, Cracow.

1986, Holocene travertine deposits of the Cracow Upland, in IAS European mtg, 7th: Excursion Guidebook, Cracow, p 185-189.

Thorpe, P M, Holydak, D T, Preece, R C and Willing, M J, 1981, Validity of corrected ${ }^{14} \mathrm{C}$ dates from calcareous tufa, in Formations carbonatées externes, tufs et travertins: Actes Colloques AGF, Paris, p 151-156.

Thorpe, P M, Otlet, R L and Sweeting, M M, 1980, Hydrological implications from ${ }^{14} \mathrm{C}$ profiling of UK tufa, in Stuiver, $M$ and Kra, R S, eds, Internatl ${ }^{14} \mathrm{C}$ conf, 10th, Proc: Radiocarbon, v 22, no. 3, p 897-908.

Usdowski, E, Hoefs, J and Menschel, $\mathrm{G}, 1979$, Relationship between ${ }^{13} \mathrm{C}$ and ${ }^{18} \mathrm{O}$ fractionation and changes in major element composition in a recent calcite-depositing spring: a model of chemical variations with inorganic $\mathrm{CaCO}_{3}$ precipitation: Earth Planetary Sci Letters,
$v 42$, p 267-276.

Vogel, J C, 1970, Carbon-14 dating of groundwater, in Isotope Hydrology: IAEA, Vienna, p 225-239. 